\title{
New Bioactive Heteroleptic Copper(II) Carboxylates: Structure, Enzymatic and DNA-Binding Studies
}

\author{
Afifa Mushtaq, ${ }^{1}$ Saqib Ali, ${ }^{1, *}$ Muhammad Nawaz Tahir, ${ }^{2}$ Hammad Ismail, ${ }^{3}$ \\ Bushra Mirza, ${ }^{3}$ Muhammad Saadiq, ${ }^{4}$ Muhammad Abdul Haleem ${ }^{4}$ \\ and Muhammad Iqbal ${ }^{4, *}$ \\ ${ }^{1}$ Department of Chemistry, Quaid-i-Azam University, Islamabad 45320, Pakistan \\ ${ }^{2}$ Department of Physics, University of Sargodha, Sargodha, Pakistan \\ ${ }^{3}$ Department of Biochemistry, Quaid-i-Azam University, Islamabad 45320, Pakistan \\ ${ }^{4}$ Department of Chemistry, Bacha Khan University, Charsadda 24420, KPK, Pakistan \\ * Corresponding author: E-mail: drsa54@ hotmail.com, saqibali@qau.edu.pk \\ Tel.: +9251 90642130; fax: +925190642241 \\ iqbalmo@yahoo.com,iqbalmo@bkuc.edu.pk \\ Tel.: Tel.: +92916002934; fax: +92916540060
}

Received: 03-02-2017

\begin{abstract}
Two new binuclear O-bridged copper(II) carboxylates with chemical formulas $\left[\mathrm{Cu}_{2}\left(3-\mathrm{ClC}_{6} \mathrm{H}_{4} \mathrm{CH}_{2} \mathrm{COO}\right)_{4}(\mathrm{phen})_{2}\right](\mathbf{1})$ and $\left[\mathrm{Cu}_{2}\left(3-\mathrm{ClC}_{6} \mathrm{H}_{4} \mathrm{CH}_{2} \mathrm{COO}\right)_{4}(\text { bipy })_{2}\right]$ (2) where phen = 1,10-phenanthroline and bipy = 2,2'-bipyridine have been synthesized and characterized by FT-IR, UV-Visible spectroscopy, CHN analysis and single crystal XRD. The results revealed distorted square pyramidal geometry around each copper atom of $\mathbf{1}$ and $\mathbf{2}$. The DNA interaction studies showed strong binding with $K_{\mathrm{b}}=5.07 \times 10^{3}$ and $4.62 \times 10^{3} \mathrm{M}^{-1}$ for $\mathbf{1}$ and $\mathbf{2}$, respectively. Both complexes showed strong enzyme inhibition, i.e., $70 \%$ and $90 \%$ for $\alpha$-glucosidase with $\mathrm{IC}_{50}=34.6$ and $30.1 \mu \mathrm{M}$ for $\mathbf{1}$ and $\mathbf{2}$, respectively, where acarbose was employed as control. However, both the complexes were found inactive against $\alpha$-amylase. Using galantamine hydrobromide as control, 1 showed moderate inhibition activity $(47 \%)$ with $\mathrm{IC}_{50}=179.4 \mu \mathrm{M}$ for acetylcholine esterase whereas 2 showed strong inhibition activity $(76 \%)$ with $\mathrm{IC}_{50}=95.8 \mu \mathrm{M}$ for butyrylcholine esterase. The data reflects active anti-diabetic and anti-Alzheimer's nature of the synthesized complexes.
\end{abstract}

Keywords: Copper(II) Carboxylates, Structure, Enzymatic study, DNA-Binding Study

\section{Introduction}

Despite decades research work in the field of metal carboxylates, these fascinating materials with diverse structures and applications have still kept interest of scientists alive in them. Since their discovery they have been serving mankind in one way or the other. The striking application of metal carboxylates is that they act as accelerators for a number of industrially and biologically important chemical reactions such as oxidations, reductions, couplings, $\mathrm{C}-\mathrm{H}$ insertions, transformations, and charge transfers. ${ }^{1-4} \mathrm{~A}$ number of bioactive metal carboxylates have also been reported to date. ${ }^{5,6}$ Inevitable relationship between chemical reactions naturally carried out within the human body, pharmacology and medicine has lead the scientists to design new bioactive materials in the form of potent drugs for therapeutic intervention in treatment of many life threatening diseases. Metal charge, interactions with ligands, structure and bonding, Lewis acid character, partially filled $d$-shell and its redox activity defines its suitability for biological systems. ${ }^{7-10}$

Copper is one of essential metals with multifaceted role in human life. It has been used as medicine for healing purposes since ancient civilizations. ${ }^{11-13}$ In case of exogenous administration in the form of synthetic compounds, it interacts with various biomolecules mainly pro- 
teins and nucleic acid. ${ }^{14,15}$ Cytochrome $\mathrm{c}$ oxidase, superoxide dismutase, ferroxidases, monoamine oxidase, and dopamine $\beta$-monoxygenase are copper dependent enzymes within the human body ${ }^{16,17}$ Recently, greater interest in copper carboxylates has emerged because of their potential use as antimicrobial, antiviral, anti-inflammatory and antitumor agents due to their ability to interact with DNA through Fenton type reaction and they offer reduced side effects attributed to their superoxide dismutase (SOD) mimetic activity. ${ }^{18,19}$ In this regard casiopeinas, generic name of heteroleptic copper(II) complexes with good antineoplastic activity have set a foundation for synthesis of therapeutically potent agents based on mix ligand copper(II) complexes. ${ }^{20,21}$ Moreover, copper complexes can act as enzyme inhibitors by blocking the active sites on enzyme surface as copper has ability to bind to various proteins in biological system. However, a very few copper carboxylates have been reported so far with alpha glucosidase, acetylcholine and butyrylcholine esterases inhibition activity. ${ }^{22-25}$

Since enzyme targeting is potential therapy in modern era of medicinal research therefore combining an essential metal and two different organic ligands together in a single molecule to develop lifesaving drugs could be attractive solution. Organic ligands in these complexes affect and regulate their activity by neutralizing the charge on copper ion and facilitating the transport across the cell membranes. ${ }^{26,27}$

Therefore, keeping in view all these facts, as well as in continuation of our previous work, ${ }^{28-30}$ the present study is designed with aim to synthesize biologically active heteroleptic copper(II) complexes with substituted phenylacetic acids and 1,10-phenanthroline and 2,2'-bipyridine. DNA binding ability of synthesized complexes was evaluated through UV-Visible spectroscopy which exhibited good results and their strong enzyme inhibition capacity revealed their therapeutic applications as well.

\section{Results and Discussion}

\section{1. Synthesis, UV-Visible and FT-IR spectroscopy}

The complexes were synthesized in aqueous medium using mild reaction conditions as depicted in Sche-<smiles>CCOC(=O)C(C)OCC</smiles><smiles>COC(=O)Cc1cccc(Cl)c1</smiles>

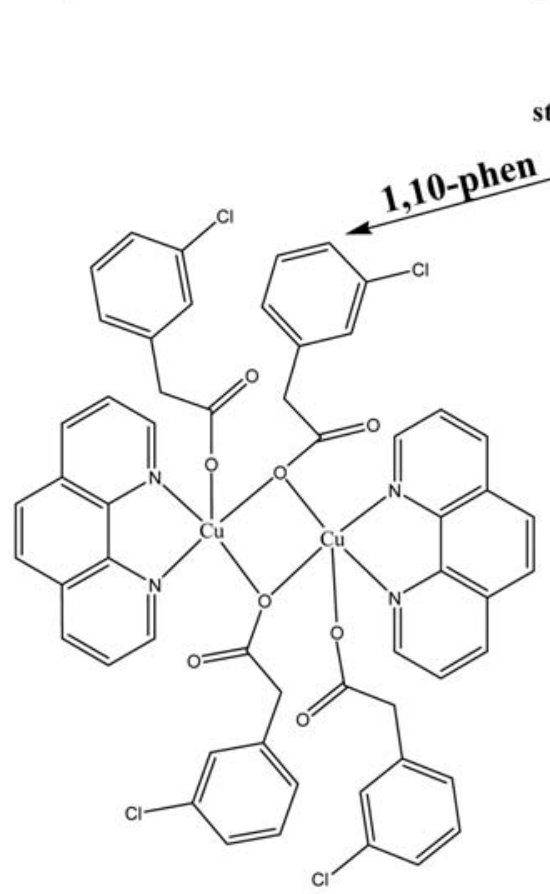

1

Scheme 1. Synthetic procedure and proposed structures of the complexes. 
me 1 . These were obtained in good yield followed by their purification and recrystallization. The crystalline samples were subjected to characterization techniques such as UV-Visible, FT-IR and single-crystal X-ray crystallographic studies. UV-Visible and FT-IR spectra clearly indicated the essential peaks that helped in characterization of the complexes. The bands observed at $673 \mathrm{~nm}$ and $663 \mathrm{~nm}$ in visible region for complexes 1 and 2 , respectively, were assigned to $\mathrm{d}-\mathrm{d}$ electronic transition of copper metal ion. These band positions are typical of those observed for other copper complexes having square pyramidal geometry. Two bands were observed in region below $400 \mathrm{~nm}$ for complex 1 . An intense band at $272 \mathrm{~nm}$ was assigned to intra-ligand $\pi \rightarrow \pi^{*}$ and $n \rightarrow \pi^{*}$ electronic transitions for aromatic rings and carbonyl group of the ligands. Second broad band at 315 correspond to ligand to metal charge transfer transition. Similarly, for complex 2 intense band at $270 \mathrm{~nm}$ corresponds to intra-ligand $\pi \rightarrow \pi^{*}$ and $\mathrm{n} \rightarrow \pi^{*}$ electronic transitions while band at 305 $\mathrm{nm}$ is assigned to ligand to metal charge transfer transition. Values of $\varepsilon$ for complexes 1 and $\mathbf{2}$ are $93.4 \mathrm{~L} \mathrm{~mol}^{-1}$ $\mathrm{cm}^{-1}$ at $\lambda_{\text {max }} 272 \mathrm{~nm}$ and $92.2 \mathrm{~L} \mathrm{~mol}^{-1} \mathrm{~cm}^{-1}$ at $\lambda_{\text {max }} 270 \mathrm{~nm}$, respectively.

Both complexes were characterized by FT-IR spectroscopy. All the characteristic bands were observed in the spectrum. Absorption bands at $2980 \mathrm{~cm}^{-1}$ and $3080 \mathrm{~cm}^{-1}$ were due to aromatic $\mathrm{C}-\mathrm{H}$ stretching for complex $\mathbf{1}$ and $\mathbf{2}$, respectively. While absorption bands at $1625 \mathrm{~cm}^{-1}$ and $1427 \mathrm{~cm}^{-1}$ represented asymmetric and symmetric $\mathrm{O}-\mathrm{C}=\mathrm{O}$ stretching modes of fully deprotonated carboxylate group in complex 1 and at $1633 \mathrm{~cm}^{-1}$ and $1444 \mathrm{~cm}^{-1}$ in complex $2 .{ }^{31}$ Absorption bands at $1519,1562 \mathrm{~cm}^{-1}$ and $1604,1566 \mathrm{~cm}^{-1}$ were assigned to aromatic $\mathrm{C}=\mathrm{C}$ stretching for complexes $\mathbf{1}$ and $\mathbf{2}$. While $\mathrm{Ar}-\mathrm{Cl}$ stretch was observed at 723 and $769 \mathrm{~cm}^{-1}$ for two complexes. Bonding of $\mathrm{Cu}(\mathrm{II})$ with $\mathrm{O}$-atom of carboxylate moiety and $\mathrm{N}$-atom of pyridine was depicted by absorption bands at 611,605 $\mathrm{cm}^{-1}$ and $482,479 \mathrm{~cm}^{-1}$ for complexes 1 and 2, respectively.

Binding mode of carboxylate moiety either monodentate or bidentate in both complexes was defined by calculating the value of $\Delta v\left\{v(\mathrm{OCO})_{\text {asym }}-v(\mathrm{OCO})_{\mathrm{sym}}\right\}$ which is 198 for complex $\mathbf{1}$ and 189 for $\mathbf{2}$ supporting monodentate and bridging coordinate binding mode in both the complexes. This fact was also confirmed by X-ray single-crystal analysis. ${ }^{32}$

\section{2. Crystal Structure Description}

The ORTEP and close packing diagrams of both complexes with the atomic numbering scheme and mode of coordination of ligands is shown in Figs. 1 and 3 and 2 and 4, respectively. The crystal data and structure refinement parameters are given in Table 1 while the selected bond lengths and angles are listed in Table 2. The crystals remained stable throughout the data collection and both the crystals were comprised of $\mathrm{Cu}$ (II) dimeric units in which each copper atom is penta-coordinated giving rise to a distorted square pyramidal geometry around each copper atom with small distortion as reflected by value of distortion factor $\tau\left(=\beta-\alpha / 60^{\circ}\right)$ which is found to be 0.172 and 0.002 for complexes 1 and $\mathbf{2}$, respectively. ${ }^{33}$

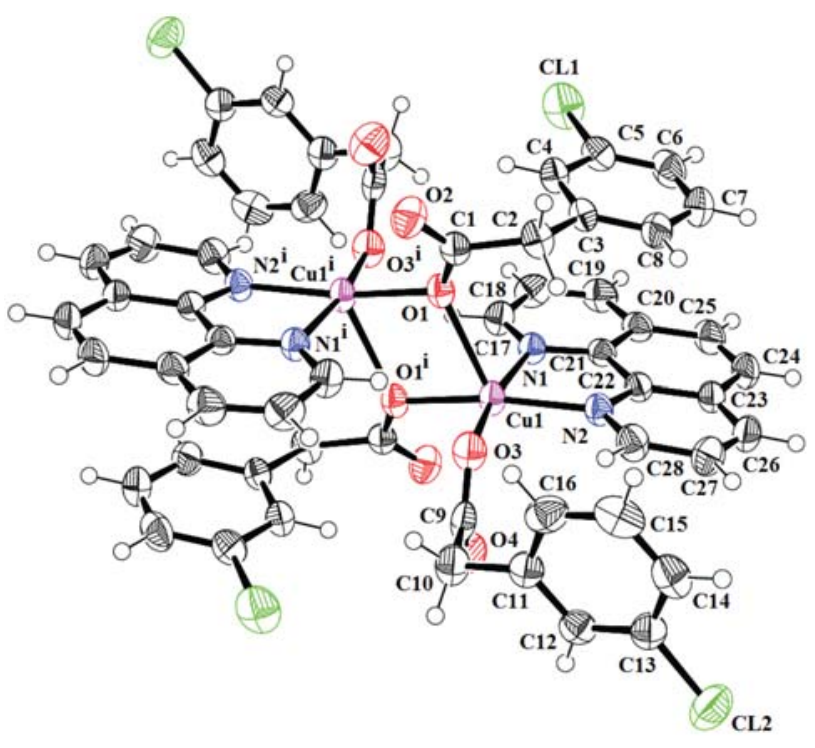

Figure 1. ORTEP diagram of complex 1 with thermal ellipsoids drawn at $50 \%$ probability level. The $\mathrm{H}$-atoms are shown as small circles of arbitrary radii. Symmetry code $\mathrm{i}=2-x,-y,-z$.

In both crystals each copper atom of a dimeric unit is surrounded by two nitrogen atoms from phen or bipy moiety and three oxygen atoms from three phenylacetic acids. Two nitrogen atoms and two oxygen occupy the four corners of a square plane while third bridging oxygen atom occupies the apical position giving rise to a square pyramidal geometry around each metal atom of a discrete dimer. The $\mathrm{Cu}-\mathrm{N}_{\text {phen }}$ and $\mathrm{Cu}-\mathrm{N}_{\text {bipy }}$ distances in complexes 1 and 2 are 2.0284(18), 2.0392(19) $\AA$ and 2.0094(19), 2.023(2) ^, respectively.

The $\mathrm{Cu}-\mathrm{O}$ apical and equatorial plane distances are different from each other. In complex $1 \mathrm{Cu}-\mathrm{O}$ equatorial plane distances are 1.9629(15), 1.9350(16) $\AA$ and in complex 2 1.9662(16), 1.9514(17) A. The apical Cu-O distance is significantly longer than equatorial ones and is 2.3678(16) A for complex 1 while 2.4053(16) A for complex 2. This lengthening of apical bond is not Jahn-Teller elongation and is attributed to the double electron occupancy of the antibonding $a_{1}\left(d_{\mathrm{z}}{ }^{2}\right)$ orbital and single occupancy of $b_{1}\left(d_{\mathrm{x}}{ }^{2}-{ }_{\mathrm{y}}{ }^{2}\right)$ leading to increased antibonding electron density along the apical $\mathrm{Cu}-$ Ligand accompanied with weak $\mathrm{Cu}-$ Ligand interaction along this axis. The angle between a $\mathrm{Cu}$ atom and two nitrogen atoms of dimer i.e., $\mathrm{N}-\mathrm{Cu}-\mathrm{N}$ is $80.58(8)^{\circ}$ and $80.26(8)^{\circ}$ for $\mathbf{1}$ and $\mathbf{2}$, res- 


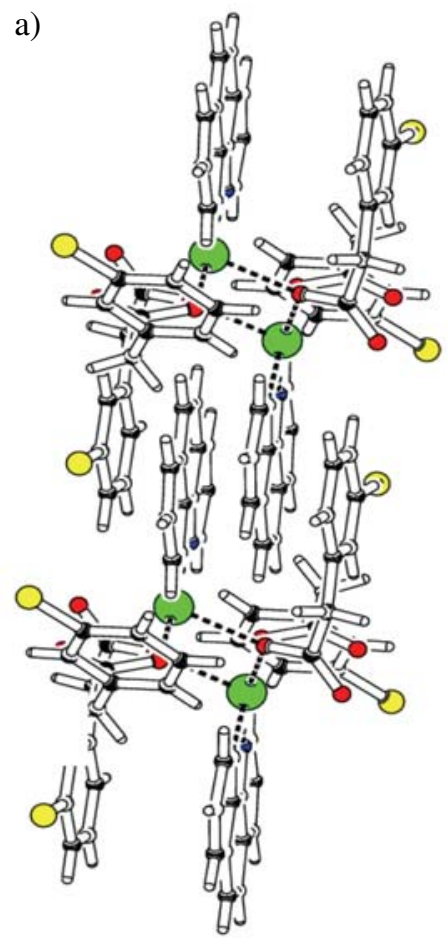

b)
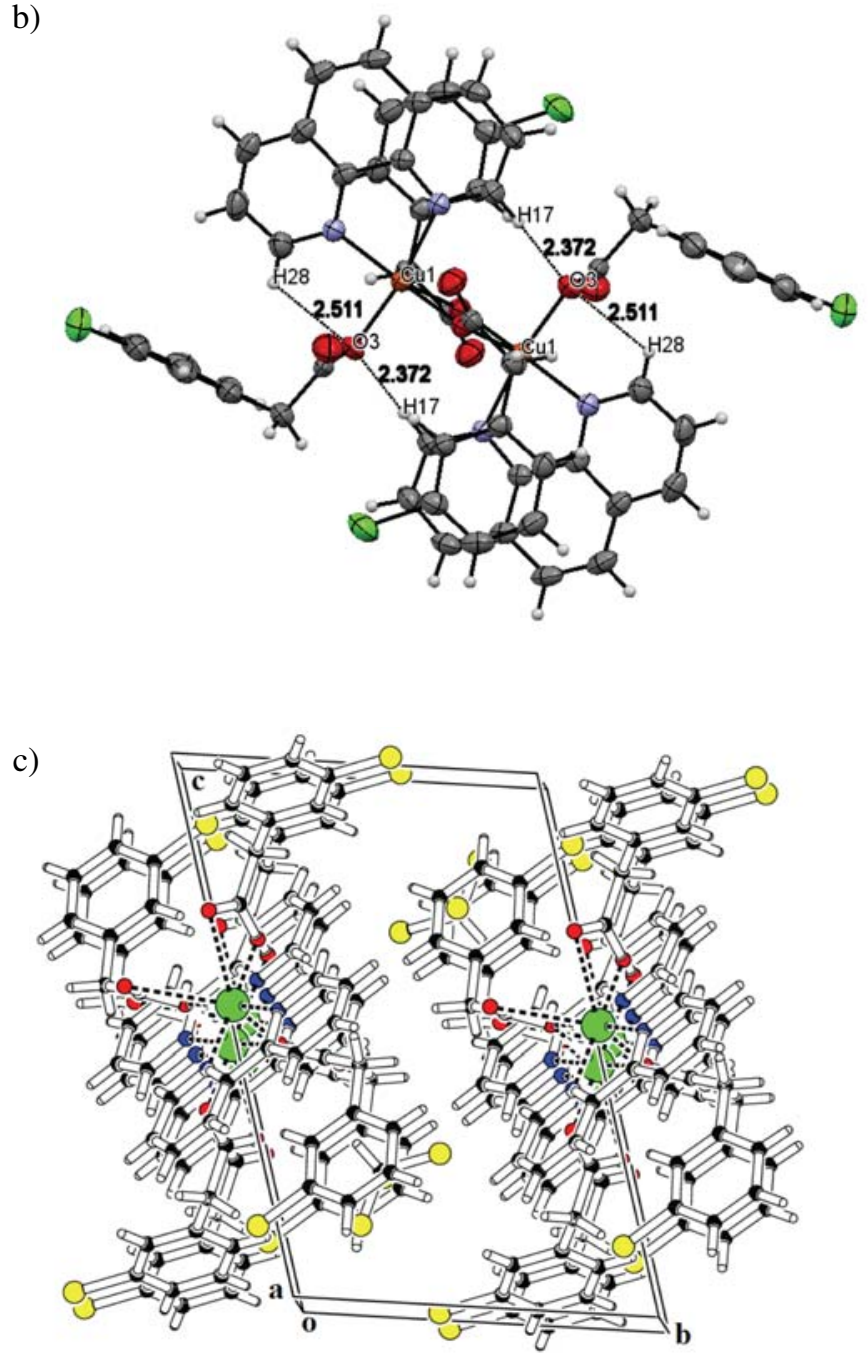

Figure 2. (a) intermolecular and intramolecular $\pi-\pi$ interactions, (b) intramolecular hydrogen bonding, (c) 3D close packing diagram of complex $\mathbf{1}$ and intermolecular hydrogen bonding.

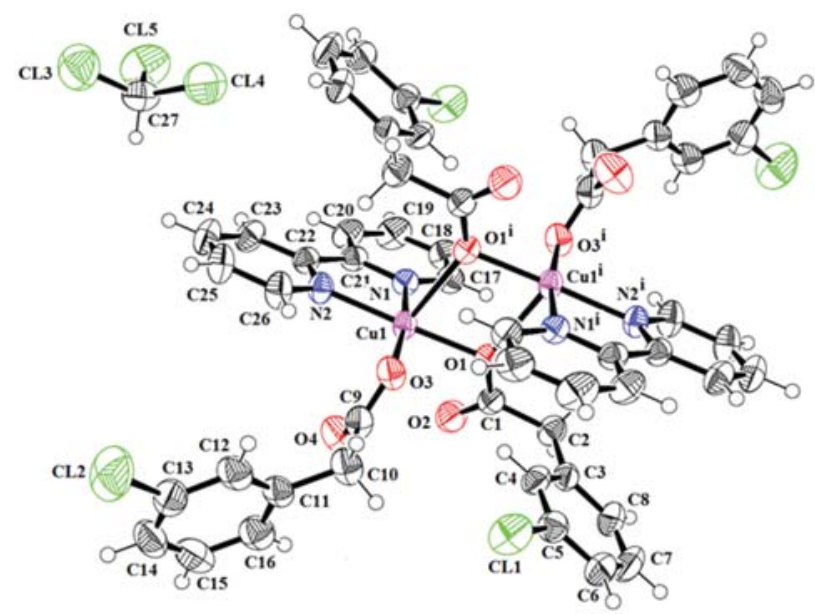

Figure 3. ORTEP diagram of complex 2 with thermal ellipsoids drawn at $50 \%$ probability level. The $\mathrm{H}$-atoms are shown as small circles of arbitrary radii. One solvent molecule $\left(\mathrm{CHCl}_{3}\right)$ has not been shown. Symmetry code $\mathrm{i}=-x, 2-y, 1-z$. pectively. ${ }^{32,34}$ Smallest angle is observed between equatorial bridging oxygen atoms and a copper atom i.e., $\mathrm{O} 1-\mathrm{Cu} 1-\mathrm{O} 1^{\mathrm{i}}$ of a dimeric unit and is equal to $76.52(6)^{\circ}$ and $77.68(7)^{\circ}$ for 1 and 2 , respectively. All the data of bond lengths and angles are comparable with previously reported similar $\mathrm{Cu}(\mathrm{II})$ complexes with $\mathrm{O}$ - and $\mathrm{N}$-donor ligands. ${ }^{35,36}$

Supramolecular interactions in complexes are different from one another owing to different dihedral planes and the presence of $\mathrm{CHCl}_{3}$ in $\mathbf{2}$. In complex $\mathbf{1}$ two molecules of 3-chlorophenylacetate form different dihedral angles around copper which enable them to take part in $\mathrm{C}-\mathrm{H} \cdots \mathrm{O}$ interactions with 1,10-phenanthroline moiety of the neighboring molecule. Thus, the bridging carboxylate moiety is involved in intramolecular $\pi-\pi$ interactions with aromatic rings of 1,10-phenanthroline. Intramolecular hydrogen bonding is present between $\mathrm{H} 17$ and $\mathrm{H} 18$ atoms of 1,10-phenanthroline and $\mathrm{O} 3$ atoms of adjacent carboxylates ligand which is coordinated to metal atom with 
a)

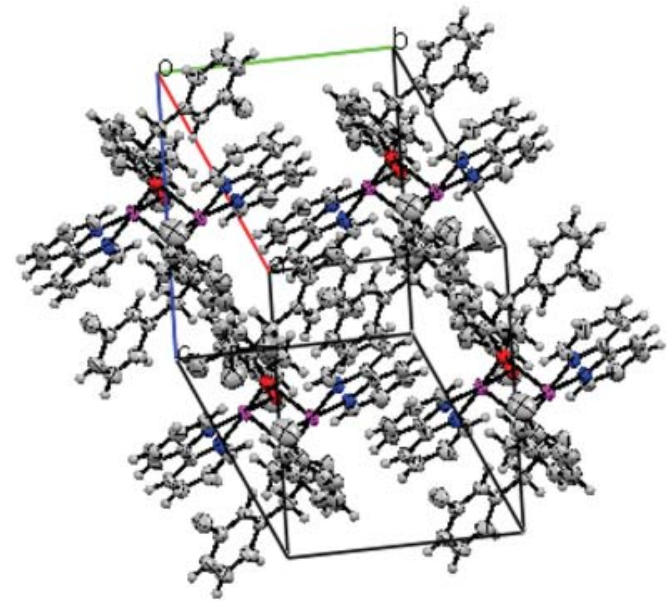

b)

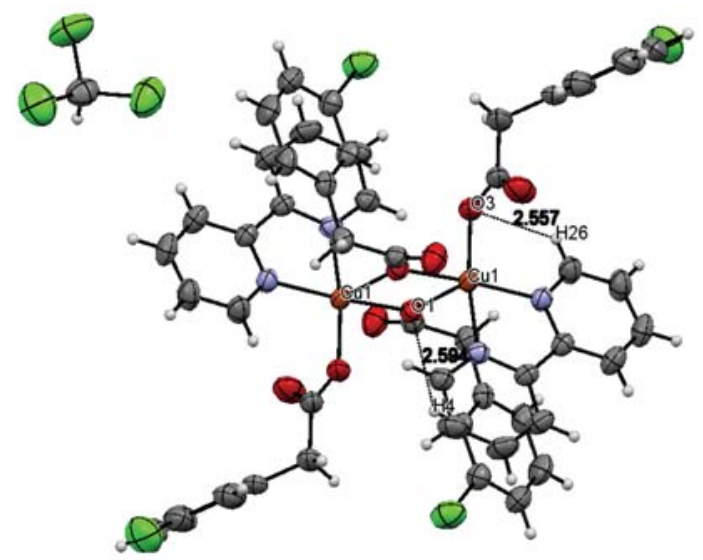

Figure 4. (a) 3D close packing diagram of complex 2, (b) intramolecular hydrogen bonding.
Table 2. Selected bond lengths and angles of the complexes

\begin{tabular}{|c|c|c|}
\hline Distances, $\AA$ & & \\
\hline & Complex 1 & Complex 2 \\
\hline $\mathrm{N} 1-\mathrm{Cu} 1$ & $2.0284(18)$ & $2.0094(19)$ \\
\hline N2-Cu1 & 2.0392(19) & $2.023(2)$ \\
\hline $\mathrm{O} 1-\mathrm{Cu} 1$ & $1.9629(15)$ & $1.9662(16)$ \\
\hline $\mathrm{O} 1-\mathrm{Cu} 1^{\mathrm{i}}$ & $2.3678(16)$ & $2.4053(16)$ \\
\hline $\mathrm{O} 3-\mathrm{Cu} 1$ & $1.9350(16)$ & $1.9514(17)$ \\
\hline \multicolumn{3}{|l|}{$\overline{\text { Angles, }}^{\circ}$} \\
\hline$\overline{\mathrm{Cu} 1-\mathrm{O} 1-\mathrm{Cu} 1^{\mathrm{i}}}$ & $103.48(6)$ & $102.32(7)$ \\
\hline $\mathrm{O} 3-\mathrm{Cu} 1-\mathrm{O} 1$ & $90.32(7)$ & $91.07(7)$ \\
\hline O3-Cu1-N1 & $169.94(8)$ & $171.26(8)$ \\
\hline $\mathrm{O} 3-\mathrm{Cu} 1-\mathrm{N} 2$ & $89.37(7)$ & $93.32(8)$ \\
\hline $\mathrm{O} 1-\mathrm{Cu} 1-\mathrm{N} 1$ & $96.46(7)$ & $95.29(7)$ \\
\hline $\mathrm{O} 1-\mathrm{Cu} 1-\mathrm{N} 2$ & $169.58(7)$ & $175.53(7)$ \\
\hline $\mathrm{N} 1-\mathrm{Cu} 1-\mathrm{N} 2$ & $80.58(8)$ & $80.26(8)$ \\
\hline $\mathrm{O} 3-\mathrm{Cu} 1-\mathrm{O} 1^{\mathrm{i}}$ & $93.39(7)$ & $91.79(7)$ \\
\hline $\mathrm{O} 1-\mathrm{Cu} 1-\mathrm{O} 1^{\mathrm{i}}$ & $76.52(6)$ & $77.68(7)$ \\
\hline $\mathrm{N} 1-\mathrm{Cu} 1-\mathrm{O} 1^{\mathrm{i}}$ & 93.91(7) & $95.41(7)$ \\
\hline $\mathrm{N} 2-\mathrm{Cu} 1-\mathrm{O} 1^{\mathrm{i}}$ & $113.54(7)$ & 102.99(7) \\
\hline
\end{tabular}

Symmetry codes: $\mathrm{i}=2-x,-y,-z$ for $\mathbf{1} ; \mathrm{i}=-x, 2-y, 1-z$ for $\mathbf{2}$.

$\mathrm{H} \cdots \mathrm{A}$ distance of 2.37 and $2.51 \AA$, respectively as shown in Fig. 2. Each monomer in crystal lattice is linked to another monomer through hydrogen bonds which arises between uncoordinated $\mathrm{O} 2$ and $\mathrm{O} 4$ atoms of carboxylate moiety and hydrogen atoms of phenanthroline rings with distance of $2.57 \AA$. In addition to this, $\mathrm{Cl}$ atoms also participate in intermolecular hydrogen bonding with near-

Table 1. Crystal data and structure refinement parameters for the complexes

\begin{tabular}{lcc}
\hline & $\mathbf{1}$ & $\mathbf{2}$ \\
\hline Empirical Formula & $\mathrm{C}_{56} \mathrm{H}_{40} \mathrm{Cl}_{4} \mathrm{Cu}_{2} \mathrm{~N}_{4} \mathrm{O}_{8}$ & $\mathrm{C}_{54} \mathrm{H}_{42} \mathrm{Cl}_{10} \mathrm{Cu}_{2} \mathrm{~N}_{4} \mathrm{O}_{8}$ \\
Formula weight $\left(\mathrm{g} \mathrm{mol}^{-1}\right)$ & 1165.80 & 1356.49 \\
Crystal system & Triclinic & Triclinic \\
Space group & $P-1$ & $P-1$ \\
Unit cell dimensions & & \\
$a(\AA)$ & $8.8156(4)$ & $9.8539(4)$ \\
$b(\AA)$ & $11.0165(6)$ & $10.3186(4)$ \\
$c(\AA)$ & $13.0297(7)$ & $15.4092(7)$ \\
$\alpha\left({ }^{\circ}\right)$ & $72.853(3)$ & $73.331(2)$ \\
$\beta\left({ }^{\circ}\right)$ & $83.183(3)$ & $73.4550(10)$ \\
$\left.\gamma^{(}\right)$ & $89.275(3)$ & $83.481(2)$ \\
$V\left(\AA^{3}\right)$ & $1200.28(11)$ & $1437.93(11)$ \\
$Z$ & 1 & 1 \\
$\rho_{\text {calc }}(\mathrm{g}$ cm & -3 & 1.566 \\
$\left.\mu(\mathrm{mm})^{-1}\right)$ & 1.613 & 1.261 \\
$F(000)$ & 1.173 & 686 \\
Reflections collected & 594 & 20560 \\
Independent Reflections & 18408 & 5608 \\
Data/Restraints/Parameters & 5187 & $5608 / 0 / 352$ \\
Goodness-of-fit on $\mathrm{F}^{2}$ & $5187 / 0 / 334$ & 1.032 \\
$R_{1}, w R_{2}$ indices [I $\left.>2 \sigma(\mathrm{I})\right]$ & 1.016 & $0.0481,0.1026$ \\
$R_{1}, w R_{2}$ indices (all data) & $0.0373,0.0871$ & $0.0375,0.0953$ \\
\hline
\end{tabular}


by $\mathrm{H}$ atoms of phenyl rings. While intermolecular $\pi-\pi$ stacking interactions between two adjacent phenanthroline rings with centroid-to-centroid distance of 3.526-3.851 $\AA$ Aive rise to strong intermolecular interaction thus providing overall stability to the crystal lattice. This stacking effect present in the complex is comparable with stacking effect present in DNA strands and enables the complex to interact with DNA through intercalation. ${ }^{37,38}$

Similar intramolecular forces as well as intermolecular forces are present in complex $\mathbf{2}$ where two solvent molecules are integral part of the unit cell and further extend the intermolecular interactions. In this complex two carboxylate ligands i.e. 3-chlorophenylacetic acid also behave differently. One carboxylate moiety around one $\mathrm{Cu}$ atom of dimer $(\mathrm{O} 1 / \mathrm{O} 2 / \mathrm{Cl} 1 / \mathrm{C} 1-\mathrm{C} 8)$, in plane $\mathrm{A}$ $(\mathrm{O} 1 / \mathrm{C} 1 / \mathrm{O} 2)$ is oriented at adihedral angle of $70.40(18)^{\circ}$ with respect to plane $\mathrm{B}(\mathrm{C} 2-\mathrm{C} 8 / \mathrm{Cl1})$. While second nonbridging carboxylate moiety $(\mathrm{O} 3 / \mathrm{O} 4 / \mathrm{Cl} 2 / \mathrm{C} 9-\mathrm{C} 16)$ in plane $\mathrm{C}(\mathrm{O} 3 / \mathrm{C} 9 / \mathrm{O} 4)$ makes dihedral angle of $56.85(24)^{\circ}$ with plane D $(\mathrm{C} 10-\mathrm{C} 16 / \mathrm{Cl} 2)$. The 2,2'-bipyridine moiety in plane $\mathrm{E}(\mathrm{N} 1 / \mathrm{N} 2 / \mathrm{C} 17-\mathrm{C} 28)$ is planar with r.m.s. deviation of 0.0500 . The dihedral angle between $\mathrm{B} / \mathrm{E}$ is $23(11)^{\circ}$. This shows that bridging carboxylate moiety is involved in intramolecular $\pi-\pi$ interactions with aromatic rings of

a)

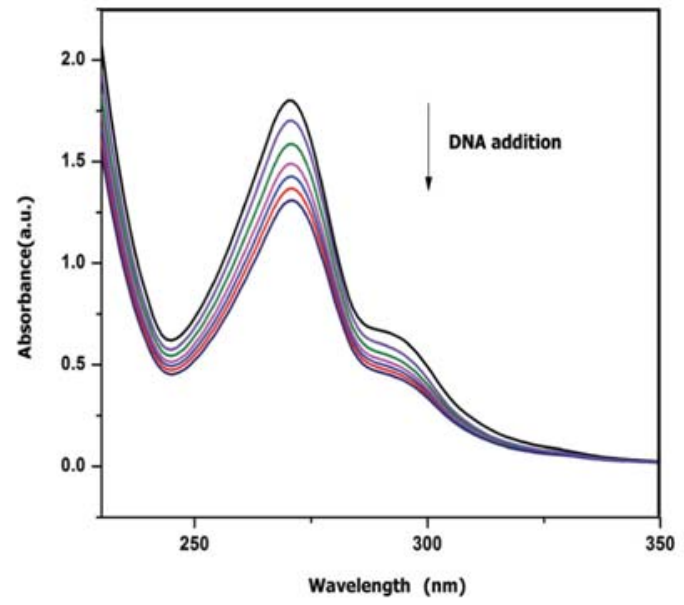

c)

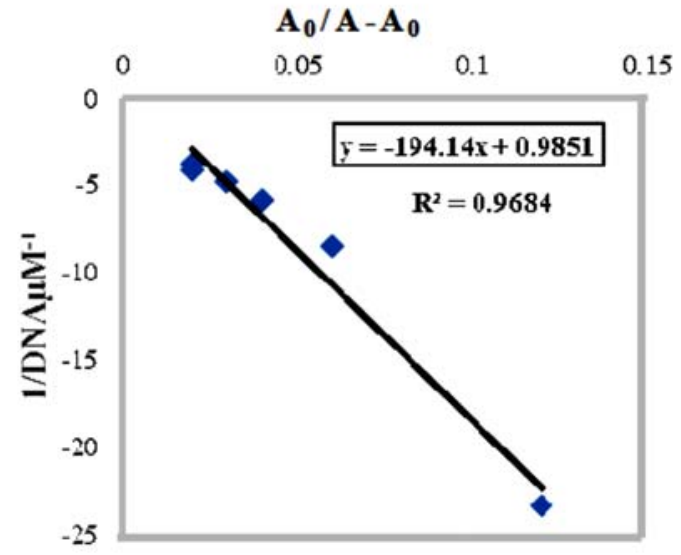

2,2 '-bipyridine. The intermolecular $\pi-\pi$ interactions arises between two adjacent bipyridine rings with centroidto-centroid distance of 3.42-3.94 $\AA$ and give rise to stack effect thus enabling this complex to interact with DNA through intercalation. ${ }^{39,40}$ Intramolecular hydrogen bonding in complex $\mathbf{2}$ is furnished by bridging oxygen atoms $\mathrm{O} 1$ and non-bridging oxygen atoms $\mathrm{O} 3$ with hydrogen atoms of phenyl rings of bipyridine as well as adjacent carboxylate ligand as shown in Fig. 4. Moreover, solvent molecules participate in intermolecular hydrogen bonding giving overall strength to the lattice.

\section{3. DNA Binding Studies Through UV-Visible Spectroscopy}

UV-Visible spectroscopy has been employed to check the binding ability, extent of binding as well as mode of interaction of two complexes with DNA as shift in $\lambda_{\max }$ and decrease in absorbance clearly indicates the mode and extent of binding of substance with DNA. A blue shift indicates electrostatic while red shift indicates intercalative binding mode. However, smaller red shift indicates groove binding mode of interactions. Both complexes showed small red shifts of 1-2 $\mathrm{nm}$ accompanied by strong

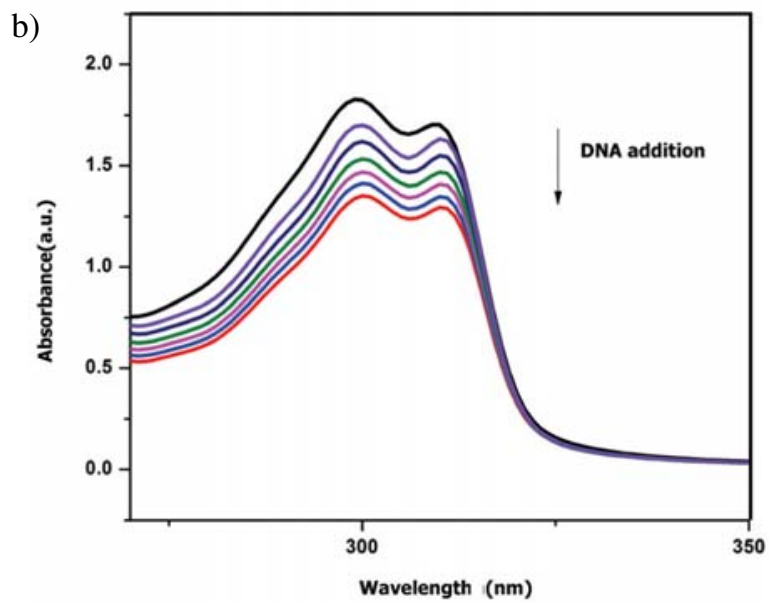

d)

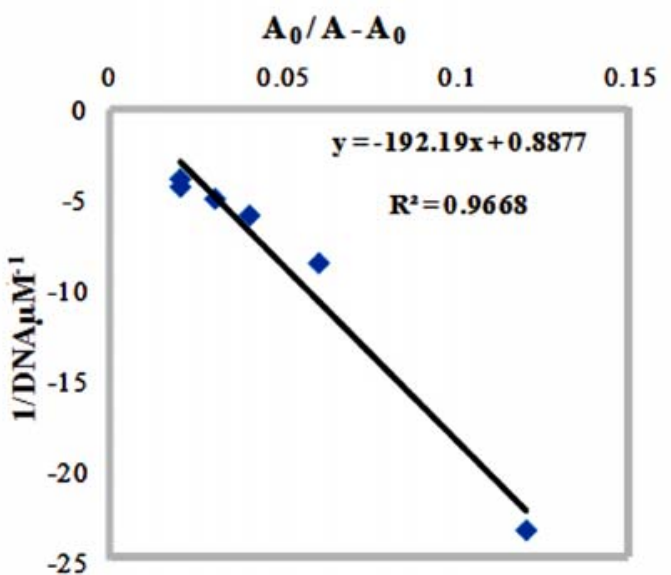

Figure 5. (a), (b) UV spectra of complexes 1 and 2. (c), (d) plots of 1/[DNA] along abscissa and $A_{\mathrm{o}} / A-A_{\mathrm{o}}$ along ordinate for $\mathbf{1}$ and $\mathbf{2}$, respectively. 
hypochromism (decrease in absorbance) with subsequent addition of SSDNA solution. All these observations suggest partial intercalative and groove binding mode of interaction for complexes $\mathbf{1}$ and $\mathbf{2}$ with SSDNA.

Extent of interaction of complexes with SSDNA was judged by calculating binding parameter such as $K_{\mathrm{b}}$ which is binding constant and tells how strongly a chemical substance interacts with SSDNA during specific study. $K_{\mathrm{b}}$ for both complexes was calculated by using famous Benesi-Hildebrand equation ${ }^{41,42}$ which is given below

$$
\frac{A_{o}}{A-A_{o}}=\frac{\varepsilon_{G}}{\varepsilon_{H-G}-\varepsilon_{G}}+\frac{\varepsilon_{G}}{\varepsilon_{H-G}-\varepsilon_{G}} \frac{1}{K[D N A]}
$$

Where $K_{\mathrm{b}}$ is binding constant, $A$ and $A_{\mathrm{o}}$ are absorbance of complex-DNA adduct and pure complex solution. [DNA] represents the concentration of SSDNA in $\mathrm{mol} / \mathrm{L}$ and $\boldsymbol{\varepsilon}_{\boldsymbol{H}-\boldsymbol{G}}, \boldsymbol{\varepsilon}_{\boldsymbol{G}}$ are molar absorption co-efficients of complex-DNA adduct and pure complex, respectively. The value of $K_{\mathrm{b}}$ was calculated from intercept to slope ratio of the plot of $1 /[\mathrm{DNA}]$ along abscissa and $A_{\mathrm{o}} / A-A_{\mathrm{o}}$ along ordinate as shown in the Fig. $5 . K_{\mathrm{b}}$ value thus calculated was found to be $5.07 \times 10^{3} \mathrm{M}^{-1}$ for complex 1 with $\Delta G=-21 \mathrm{~kJ}$, and $4.62 \times 10^{3} \mathrm{M}^{-1}$ for complex 2 with $\Delta G=$ $-20 \mathrm{~kJ}$. These values of binding constants are comparable with previously reported complexes of copper which bind with DNA. ${ }^{43,44}$ Intercalative interaction of both complexes with SSDNA is attributed to $\pi-\pi$ stacking effect present in synthesized complexes which is comparable with stack effect present in DNA strand. Moreover negative $\Delta G$ values reflect the spontaneity of these interactions. ${ }^{45,46}$

A 24 hrs absorption spectroscopic study of 0.2 $\mathrm{mM} / \mathrm{MeOH}$ solutions of these complexes in visible region was carried in order to elucidate the structural stability of synthesized complexes in solution. It was observed that no shift in $\lambda_{\text {max }}$ occurred during 24 hrs (Fig. 6a, b) confirming that square pyramidal geometry around copper atom

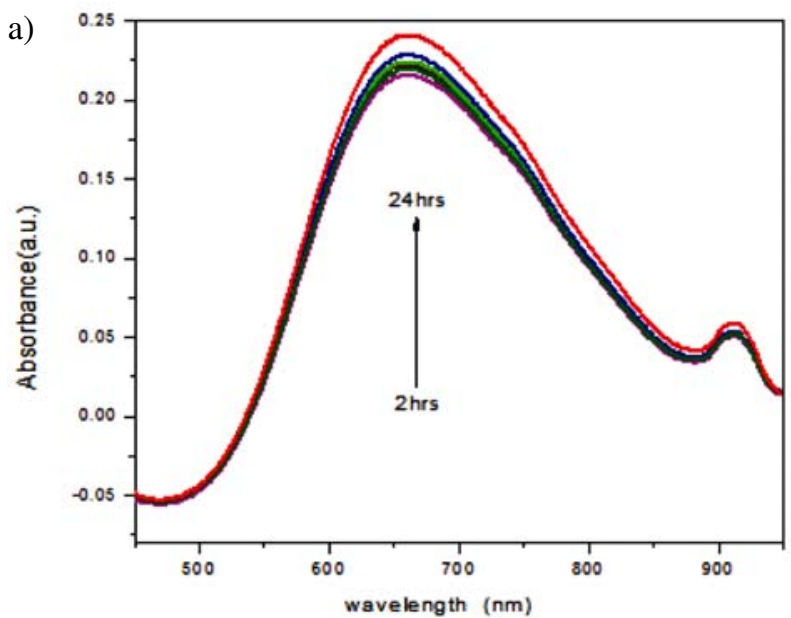

remains intact. On the basis of this observation it was proposed that both complexes might remain in dimeric form within the solution. However, a little increase in absorbance was noted which was attributed to local temperature variations during $24 \mathrm{hrs}$.

\section{4. Enzyme Inhibition Study of Complexes}

\section{4. 1. $\alpha$-Glucosidase Inhibition Assay}

$\alpha$-Glucosidase is an enzyme present in brush border of small intestine consisting of 952 amino acids with complex structure. It breaks down starch and disaccharides to glucose. Active sites of this enzyme consist of both electrophilic and nucleophilic centers. Blocking these active sites through suitable chemical agents can lead to its inactivity. Although copper ions have been found to lower the blood glucose level in diabetic patients yet, only few copper(II) complexes with amino acids and Schiff bases have been reported to date having $\alpha$-glucosidase inhibitory activity. ${ }^{47,48}$ No structurally similar complexes like those described here have been reported to date having $\alpha$-glucosidase inhibitory activity. Keeping in view all these facts, in vitro anti-diabetic activity of synthesized complexes was investigated against pure $\alpha$-glucosidase enzyme using PNG as a substrate and was compared with acarbose. Acarbose is a standard drug for $\alpha$-glucosidase inhibitor which showed an $\mathrm{IC}_{50}$ value of $13.10 \mu \mathrm{M}$ (Table 3 ). Acarbose binds reversibly with active sites of $\alpha$-glucosidase enzyme and inhibits its activity through competitive mode. Both synthesized complexes showed good $\alpha$-glucosidase inhibitory activity in a dose dependent manner. The highest inhibitory activity was recorded for the compound 2 which exhibited $94 \%$ activity with $\mathrm{IC}_{50} 30.1 \mu \mathrm{M}$ while compound 1 showed $78 \%$ inhibition with $\mathrm{IC}_{50}$ value of $34.6 \mu \mathrm{M}$ at the same concentration. It is interesting to note that $\mathrm{IC}_{50}$ values (Table 3 ) of both compounds are comparable representing their active anti-diabetic nature. This

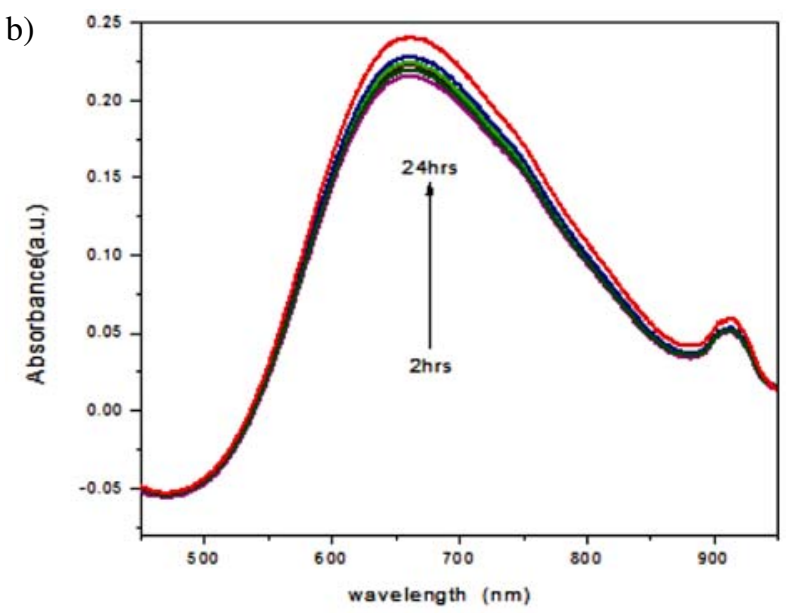

Figure 6. 24 hrs visible spectra of $0.2 \mathrm{mM} / \mathrm{MeOH}$ solutions of (a) 1 and (b) 2 . 
percentage inhibition exhibited by synthesized complexes is found to be greater than previously reported $\mathrm{Cu}$ (II) complexes with nitrogen donor ligands like ethylenediamine. ${ }^{49} \mathrm{~A}$ graph was plotted by taking\% inhibition along $y$-axis and concentration of inhibitor along $x$-axis to check the mode of inhibition of complexes $\mathbf{1}$ and $\mathbf{2}$ as shown in Fig. 7. Both complexes exhibited enzyme inhibition activity in dose dependent manner.

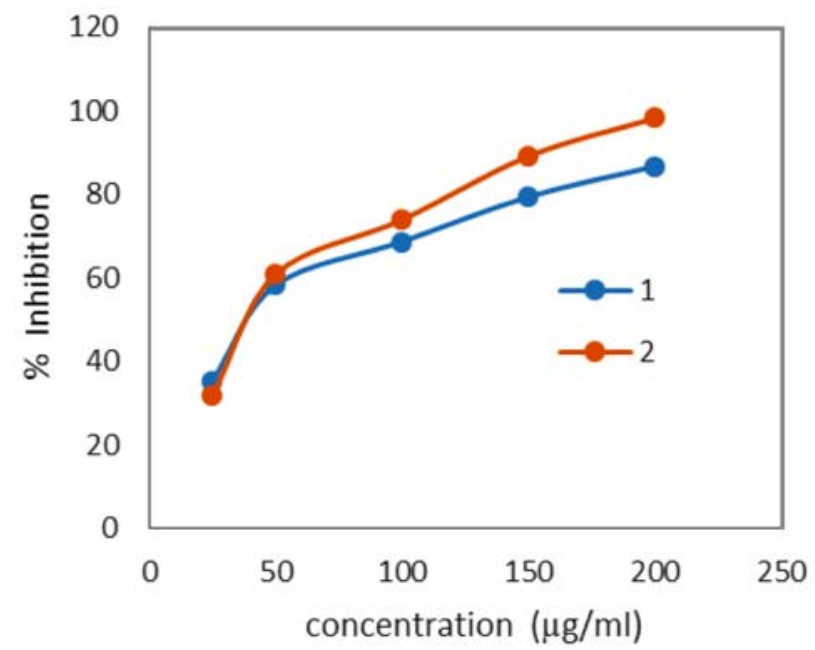

Figure 7. Plot of concentration of $\mathbf{1}$ and $\mathbf{2}$ against\% inhibition of enzyme.

It is proposed that in synthesized copper complexes the presence of fused pyridines and carboxylate ligands facilitates the transport of these complexes across the cell membrane and structural flexibility provided by carboxylate ligand enhances the chances of binding metal center of the complex with electron donors such as nitrogen present on the active site of enzyme and eventually inhibiting its activity. Moreover, from the literature it is evident that higher the capacity of inhibitor to establish hydrogen bonds with hydrogen donor and acceptors centers present on active site of an enzyme higher will be the inhibitory activity. Non-coordinated oxygen atoms of carboxylate ligands in these complexes provide opportunity to complexes to develop hydrogen bonds with amino-acids Thr-215
(H-bond acceptor) and Ser-244 (H-bond donor) present on active site of $\alpha$-glucosidase enzyme. This arrangement thus partially blocks the active sites for incoming substrate and finally partially inhibits its activity. The results of the assay reflected that these complexes have potential to inhibit this enzyme and can be suggested that such complexes incorporating copper as metal center and easily available ligands can provide a foundation in drug designing to cure type-II diabetes mellitus in future. ${ }^{50,51}$

\section{4. 2. Anticholinesterase Assays}

Acetylcholinesterases are critically important CNS and PNS enzymes that hydrolyze the neurotransmitter acetylcholine. The anticholinesterase activity of these new complexes was investigated in vitro using purified $\mathrm{AChE}$ and BChE enzymes and the results are summarized in Table 3. Galantamine hydrobromide is used as standard drug for $\mathrm{AChE}$ and $\mathrm{BChE}$ enzyme inhibitor which showed an $\mathrm{IC}_{50}$ value of 2.97 and $4.69 \mu \mathrm{M}$, respectively (Table 3 ). This drug is successfully employed for the treatment of Alzheimer disease. It is reversible competitive inhibitor of acetylcholinesterase. As copper complexes have ability to bind with various proteins and because of encouraging results of $\alpha$-glucosidase enzyme inhibition assay, the synthesized complexes were further tested for their anticholinesterase capacity. The results of our assay showed that compound $\mathbf{1}$ showed moderate activity only against $\mathrm{AChE}$ with $\mathrm{IC}_{50}$ value of $179.4 \mu \mathrm{M}$. On the other hand compound $\mathbf{2}$ showed good inhibitory activity against $\mathrm{BChE}$ with $76.3 \%$ inhibition at $200 \mu \mathrm{g} / \mathrm{mL}$ with $\mathrm{IC}_{50}$ value $95.8 \mu \mathrm{M}$. This moderate enzyme inhibition capacity of complexes is attributed to their ability of blocking the active sites on enzyme surface because of presence of electrophile and nucleophile acceptor centers present in the synthesized complexes. ${ }^{52,53}$ Some copper complexes with curcumin and bis(thiosemicarbazones) have been reported which exhibit anti-Alzheimer activity through different routes, while other copper complexes with 2-(diphenylmethylene)hydrazinecarbothioamide, Schiff bases and flavanone have shown good anticholinesterase activity, yet no heteroleptic copper(II) complexes with phenyl acetic acid and N-donor ligands have been

Table 3. Enzyme inhibition activity of the newly synthesized compounds

\begin{tabular}{ccccc}
\hline Sr. No. & Complexes & $\begin{array}{c}\text { o-glucosidase } \\
\text { inhibition }\end{array}$ & $\begin{array}{c}\mathbf{I C}_{\mathbf{5 0}}(\boldsymbol{\mu M}) \\
\text { Acetylcholinesterase } \\
\text { inhibition }\end{array}$ & $\begin{array}{c}\text { Butyrlcholineestrase } \\
\text { inhibition }\end{array}$ \\
\hline 1 & I & 34.6 & 179.4 & - \\
2 & II & 30.1 & - & 95.8 \\
3 & Acarbose & 13.10 & N.A & N.A \\
4 & Galantamine hydrobromide & N.A & 2.97 & 4.69 \\
\hline
\end{tabular}

Where "N.A" means not applicable and "-" represents no activity 
reported so far having anti-Alzheimer activity. So, all these findings can help in future drug designing for Alzheimer disease. ${ }^{54,55}$

\section{Experimental}

\section{1. Materials and Methods}

All the analytical grade chemicals used in the study were purchased from Fluka, Switzerland, and used as received. Analytical grade methanol and chloroform were obtained from Merck, Germany, and were used without further purification. Doubly distilled water was used for synthesis. Melting points of both complexes were obtained in a capillary tube using Gallenkamp, serial number C040281, U.K, electrothermal melting point apparatus. CHN analysis was carried out with a Perkin-Elmer 2400 series-II instrument. FT-IR spectra were recorded on a Nicolet-6700 FT-IR spectrophotometer, Thermoscientific, USA, in the range of 4000 to $400 \mathrm{~cm}^{-1}$. UV-Visible spectra of $\mathbf{1}$ and $\mathbf{2}$ were recorded by employing UV-1800 Shimadzu spectrometer within wavelength range of 190-800 $\mathrm{nm}$ where lower cut off region was found to be $220 \mathrm{~nm}$. For UV-visible measurements $0.2 \mathrm{mM}$ solutions of $\mathbf{1}$ and 2 were prepared in methanol at room temperature.

\section{2. Synthesis of 1 and 2}

One-pot synthesis scheme was employed for synthesis of both complexes by subsequent addition of $\mathrm{NaHCO}_{3}$ $(0.42 \mathrm{~g}, 5.0 \mathrm{mmol})$ to 3 -chlorophenylacetic acid $(0.85 \mathrm{~g}$, $5.0 \mathrm{mmol}$ ) in distilled water at $60^{\circ} \mathrm{C}$ with continuous stirring. When effervescence was stopped in the reaction mixture aqueous solution of copper sulphate $(0.72 \mathrm{~g}, 2.5$ mmol) was added drop wise and mixture was stirred for next three hours. After that, 1,10-phenanthroline $(0.49 \mathrm{~g}$, $2.5 \mathrm{mmol}$ ) for complex 1 and 2,2'-bipyridine ( $0.40 \mathrm{~g}, 2.5$ mmol) for complex 2 was added in reaction mixture and stirring was continued for next three hours. Precipitates of both complexes were separated from the reaction mixture by filtration and washed thoroughly with distilled water and air dried. Later on both complexes were recrystallized from chloroform and analyzed by FT-IR and X-ray single crystal analyses.

Dark blue crystals (1); yield (75\%). Anal. Calcd. for $\mathrm{C}_{56} \mathrm{H}_{40} \mathrm{Cl}_{4} \mathrm{Cu}_{2} \mathrm{~N}_{4} \mathrm{O}_{8}(\%)$ : calc. C, $57.64 \% ; \mathrm{H}, 3.43 \% ; \mathrm{N}$, $4.80 \%$; found: $\mathrm{C}, 56.45 \%$; $\mathrm{H}, 3.23 \%$; N, $4.54 \%$; m.p. 171-172 ${ }^{\circ} \mathrm{C}$; FT-IR $\left(\mathrm{cm}^{-1}\right): 1625 v(\mathrm{OCO})_{\text {asym }}, 1427$ $v(\mathrm{OCO})_{\text {sym }}, \Delta v=198,2980 v(\mathrm{Ar}-\mathrm{H}), 1519,1562$ $v \operatorname{Ar}(\mathrm{C}=\mathrm{C}), 723 v(\mathrm{Ar}-\mathrm{Cl}), 611 v(\mathrm{Cu}-\mathrm{O}), 482 v(\mathrm{Cu}-\mathrm{N}) ; \varepsilon$ $=93.4 \mathrm{~L} \mathrm{~mol}^{-1} \mathrm{~cm}^{-1}$.

Light blue crystals (2); yield (70\%) Anal. Calcd. for $\mathrm{C}_{54} \mathrm{H}_{42} \mathrm{Cl}_{10} \mathrm{Cu}_{2} \mathrm{~N}_{4} \mathrm{O}_{8}(\%)$ : calc. C, $47.77 \%$; $\mathrm{H}, 3.09 \% ; \mathrm{N}$, $4.13 \%$; found: C, $46.87 \%$; $\mathrm{H}, 2.93 \%$; N, $4.05 \%$; m.p. 164-165 ${ }^{\circ} \mathrm{C}$; FT-IR $\left(\mathrm{cm}^{-1}\right): 1633 v(\mathrm{OCO})_{\text {asym }}, 1444$ $v(\mathrm{OCO})_{\mathrm{sym}}, \Delta v=189,3080 v(\mathrm{Ar}-\mathrm{H}), 1604,1566$ $v \operatorname{Ar}(\mathrm{C}=\mathrm{C}), 769 v(\mathrm{Ar}-\mathrm{Cl}), 605 v(\mathrm{Cu}-\mathrm{O}), 479 v(\mathrm{Cu}-\mathrm{N})$; $\varepsilon=92.2 \mathrm{~L} \mathrm{~mol}^{-1} \mathrm{~cm}^{-1}$.

\section{3. X-ray Crystallographic Study}

Crystallographic data were collected at $296 \mathrm{~K}$ using an Oxford Gemini Ultra S CCD diffractometer using graphite monochromatic Mo-K $\alpha$ radiations $(\lambda=0.71073$ $\AA$ ). Data reduction and empirical absorption corrections were accomplished using CrysAlisPro. Structures were solved by direct methods using SHELXS-86 and refined by full matrix least-squares analysis against $F^{2}$ with SHELXL-2014/7 within the WinGX package. The drawings of the complexes were produced using ORTEP3 ${ }^{56-58}$

\section{4. DNA Interaction Studies by Absorption Spectroscopy}

Suitable amount of salmon sperm DNA (SSDNA) was dissolved in distilled water and stirred for overnight before use. The nucleotide to protein $(\mathrm{N} / \mathrm{P})$ ratio of $\sim 1.7$ was obtained from the ratio of absorbance at $260 \mathrm{~nm}$ and $280 \mathrm{~nm}\left(A_{260} / A_{280}=1.7\right)$, for prepared DNA solution which indicated that solution is free of proteins. The SSDNA concentration was determined by absorption spectroscopy using molar absorption coefficient of $6600 \mathrm{M}^{-1} \mathrm{~cm}^{-1}$ $(260 \mathrm{~nm})$ for SSDNA. Solutions of both complexes for UV-Visible spectrophotometric analysis were prepared in methanol at a concentration of $0.2 \mathrm{mM}$. The absorption titrations were performed by keeping complexes concentration constant with change of SSDNA at the rate of $150 \mu \mathrm{L}$ to aliquots to eliminate the absorbance of SSDNA itself. The solutions were allowed to incubate for $30 \mathrm{mins}$ at room temperature before the measurements were made. Absorption spectra were recorded using cuvettes of $1 \mathrm{~cm}$ path length at room temperature.

\section{4. Enzyme Inhibition Assays}

\section{4. 1. $\alpha$-Glucosidase and Amylase Inhibition}

Anti-diabetic property of synthesized complexes was evaluated by previously reported $\alpha$-glucosidase enzyme inhibition assay with modifications. ${ }^{59} \alpha$-glucosidase from Saccharomyces cerevisiae (Sigma-Aldrich) was dissolved in $50 \mathrm{mM}$ potassium phosphate buffer $(\mathrm{pH}$ $6.8)$ to make enzyme stock solution ( 1 unit $/ \mathrm{mL})$ and $p$-nitrophenyl- $\alpha$-D-glucopyranoside (PNG) prepared in same buffer at $20 \mathrm{mM}$ was used as substrate. Assay was performed in triplicate in 96-well plates and samples were prepared in DMSO with 200, 100 and 50 ppm final concentration. For experiment, in each well $25 \mu \mathrm{L}$ of PNG, 65 $\mu \mathrm{L}$ of phosphate buffer $(50 \mathrm{mM}, \mathrm{pH} 6.8), 5 \mu \mathrm{L}$ of test sample and $5 \mu \mathrm{L}$ of $\alpha$-glucosidase enzyme $(0.05 \mathrm{U} / \mathrm{mL})$ were used. Acarbose and DMSO were used as positive and negative controls, respectively. Plates were incubated 
at $37{ }^{\circ} \mathrm{C}$ for $30 \mathrm{~min}$, followed by addition of $0.5 \mathrm{mM}$ sodium bicarbonate $(100 \mu \mathrm{L})$ as stopping agent. Percentage activity was measured by the following formula after taking absorbance $(A)$ at $405 \mathrm{~nm}$ using microplate reader (BioTek Elx-800, USA). IC $_{50}$ was calculated by using Graph pad Prism 5 according to the equation:

$\%$ Inhibition $=\left[\left(A_{\text {control }}-A_{\text {sample }}\right) / A_{\text {control }}\right] \times 100$

\section{4. 2. Anticholinesterase Assays}

The anticholinesterase potential of newly synthesized complexes was determined by the previously reported colorimetric method with modifications. ${ }^{60}$ In this study, acetylcholineestrase (AChE) and butyrlcholineestrase (BChE) activity assay was performed by using acetylthiocholine iodide $(\mathrm{AChI})$ and butyrylthiocholine iodide $(\mathrm{BChI})$ as substrates, respectively. Assay was performed in triplicate in 96-well plates and samples were prepared in DMSO with 200,100 and $50 \mathrm{ppm}$ final concentration. $5 \mu \mathrm{L}$ of sample, $20 \mu \mathrm{L}$ of $0.1 \mathrm{mM}$ sodium phosphate buffer $(\mathrm{pH}$ 8.0) and $5 \mu \mathrm{L}$ enzyme preparation $(0.05 \mathrm{U} / \mathrm{mL})$ of $\mathrm{AChE}$ and $\mathrm{BChE}$, respectively. Then $10 \mu \mathrm{L}$ substrate solution was added with final concentrations of $15 \mathrm{mM}$ for $\mathrm{AChI}$ and 4 $\mathrm{mM}$ for BChI followed by the addition of $60 \mu \mathrm{L}$ DTNBphosphate-ethanol reagent $(3 \mathrm{mM})$. The reaction mixtures were then incubated for $30 \mathrm{~min}$ at $37{ }^{\circ} \mathrm{C}$. Galantamine hydrobromide (Sigma) and DMSO were used as positive and negative controls, respectively. Percentage activity was measured by the following formula after taking absorbance $(A)$ at $405 \mathrm{~nm}$ using microplate reader (BioTek Elx-800, USA). IC $_{50}$ was calculated by using Graphpad Prism 5 according to the equation: ${ }^{61}$

$$
\% \text { Inhibition }=\left[\left(A_{\text {control }}-A_{\text {sample }}\right) / A_{\text {control }}\right] \times 100
$$

\section{Conclusion}

Two isostructural dimeric heteroleptic $\mathrm{Cu}$ (II) complexes have been synthesized and characterized by UVVisible, FTIR and XRD techniques. The data revealed slightly distorted square pyramidal geometry around each $\mathrm{Cu}$ atom and monodentate coordination mode of carboxylate ligands with metal atom in both complexes. DNA binding ability is checked through UV-Visible spectroscopy which revealed strong binding tendency of both complexes with SSDNA with $K_{\mathrm{b}}=5.07 \times 10^{3} \mathrm{M}^{-1}$ for complex 1 with $\Delta G=-21 \mathrm{~kJ}$, and $K_{\mathrm{b}}=4.62 \times 10^{3} \mathrm{M}^{-1}$ for complex 2 with $\Delta G=-20 \mathrm{~kJ}$. Enzyme inhibition assay of both complexes disclosed their potential therapeutic applications as anti-diabetic as well as anti-Alzheimer's disease in dose dependent manner with $\mathrm{IC}_{50}(\mu \mathrm{M})$ values of 34.6 and 30.1 for $\alpha$-glucosidase for complexes $\mathbf{1}$ and $\mathbf{2}$, respectively. $\mathrm{IC}_{50}$ values for acetylcholinesterase and butyrlcholineestrase were found to be 179.4 and $95.8 \mu \mathrm{M}$ for complexes $\mathbf{1}$ and $\mathbf{2}$, respectively. On the basis of this data we proposed that both synthesized complexes are biologically acti- ve and in future could provide a solid foundation in drug designing.

\section{Acknowledgements}

We would like to thank Higher Education Commission of Pakistan for providing financial support for the research work. We are also thankful for single-crystal analysis undertaken at Department of Physics, University of Sargodha, Pakistan.

\section{Appendix A. Supplementry data}

Crystallographic data for the structures reported in this paper has been deposited with the Cambridge Crystallographic Data Centre, CCDC \#1473940 and 1473941 for 1 and $\mathbf{2}$ respectively. Copies of this information may be obtained free of charge from The Director, CCDC, 12, Union Road Cambridge CB2 1EZ [Fax: +44 (1223)336 033] or e.mail: deposit @ ccdc.cam.ac.uk.

\section{References}

1. S. Kannan, G. Venkatachalam, H. J. Lee, B. K. Min, W. Kim, E. Koo, Y. R. Do, S. Yoon, Polyhedron 2011, 30, 340-346. https://doi.org/10.1016/j.poly.2010.10.019

2. L. N. Jin, Q. Liu, W. Y. Sun, Cryst. Eng. Comm. 2014, 16, 3816-3828. https://doi.org/10.1039/c3ce41962b

3. J. Hansen, B. Li, E. Dikarev, J. Autschbach, H. M. L. Davies, J. Org. Chem. 2009, 17, 6564-6571. https://doi.org/10.1021/jo900998s

4. J. C. Zhong, F. Wan, Y. Q. Sun, Y. P. Chen, J. Solid State Chem. 2015, 221, 14-20. https://doi.org/10.1016/j.jssc.2014.08.037

5. R. Jayakumar, M. Rajkumar, R. Nagendran, S. Nanjundan, J. Appl. Polym. Sci. 2002, 85, 1194-1206. https://doi.org/10.1002/app.10694

6. M. V. Marinho, M. I. Yoshida, K. J. Guedes, K. Krambrock, A. J. Bortoluzzi, M. Horner, F. C. Machado, W. M. Teles, Inorg. Chem. 2004, 43, 1539-1544. https://doi.org/10.1021/ic035251y

7. L. You, W. Zong, G. Xiong, F. Ding, S. Wang, B. Ren, I. Dragutan, V. Dragutan, Y. Sun, Appl. Catal., A 2016, 511, 1-10.

8. K. L. Haas, K. J. Franz, Chem. Rev. 2009, 109, 4921-4960. https://doi.org/10.1021/cr900134a

9. T. K. Sawyer, Chem. Biol. Drug. Des. 2006, 67, 196-200. https://doi.org/10.1111/j.1747-0285.2006.00371.x

10. R. Vafazadeh, N. Hasanzade, M. M. Heidari, A. C. Willis, Acta Chim. Slov. 2015, 62, 122-129 https://doi.org/10.17344/acsi.2014.797

11. S. P. Fricker, Dalton Trans. 2007, 43, 4903-4917. https://doi.org/10.1039/b705551j

12. S. J. Lippard, J. M. Berg, Principles of Bioinorganic Chemi- 
stry, University Science Books, Mill Valley, 1994, 411-412.

13. R. H. Holm, P. Kennepohl, E. I. Solomon, Chem. Rev. 1996, 96, 2239-2314. https://doi.org/10.1021/cr9500390

14. S. Mandal, R. Sadhukhan, U. Ghosh, S. Mandal, M. Saha, R. J. Butcherd, N. C. Sahaa, J. Coord. Chem. 2016, 69, 16181634. https://doi.org/10.1080/00958972.2016.1174773

15. R. Vafazadeh, F. Jafari, M. M. Heidari, A. C. Willis, J. Coord. Chem. 2016, 69, 1313- 1325. https://doi.org/10.1080/00958972.2016.1163547

16. G. J. Brewer, J. Am. Coll. Nutr. 2009, 28, 238-242. https://doi.org/10.1080/07315724.2009.10719777

17. K. Balamurugan, W. Schaffner, BBA Mol. Cell. Res. 2006, 1763, 737-746.

18. R. Vafazadeh, Z. Moghadas, A. C. Willis, J. Coord. Chem. 2015, 68, 4255-4271. https://doi.org/10.1080/00958972.2015.1096349

19. N. Shahabadi, S. M. Fili, M. Shahlaei, J. Coord. Chem. 2015, 68, 3667-3684. https://doi.org/10.1080/00958972.2015.1078897

20. O. O. E. Onawumi, O. O. P. Faboya, O. A. Odunola, T. K. Prasad, M. V. Rajasekharan, Polyhedron 2008, 27, 113-117. https://doi.org/10.1016/j.poly.2007.08.041

21. F. Tisato, C. Marzano, M. Porchia, M. Pellei, C. Santini, Med. Res. Rev. 2010, 30, 708-749.

22. J. O. Noyce, H. Michels, C. W. Keevil, Appl. Environ. Microb. 2007, 73, 2748-2750.

https://doi.org/10.1128/AEM.01139-06

23. G. Borkow, J. Gabbay, FASEB J. 2004, 18, 1728-1730.

24. Z.-J. Chen, C.-N. Xu, J.-L. Zhu, D.-D. Yang, S.-S. Zhao, Y.N. Chen, S.-S. Qian, Acta Chim. Slov. 2016, 63, 165-172. https://doi.org/10.17344/acsi.2015.2109

25. Y. Wang, X. Zhang, Q. Zhang, Z. Yang, BioMetals. 2016, 23, 265-273. https://doi.org/10.1007/s10534-009-9284-6

26. T. Suksrichavalit, S. Prachayasittikul, C. N. Chartchalerm, I. N. Ayudhya, V. Prachayasittikul, Eur. J. Med. Chem. 2009, 44, 3259-3265. https://doi.org/10.1016/j.ejmech.2009.03.033

27. M. Hazra, T. Dolai, A. Pandey, S. Kumar Dey, A. Patra, Bioinorg. Chem. Appl. 2014, 2014, 1-13.

28. N. Ali, M. N. Tahir, S. Ali, M. Iqbal, K. S. Munawar, S. Perveen, J. Coord. Chem. 2014, 67, 1290-1308 https://doi.org/10.1080/00958972.2014.910653

29. S. T. Hafeez, S. Ali, M. N. Tahir, M. Iqbal, K. S. Munawar, J. Coord. Chem. 2014, 67, 2479-2495 https://doi.org/10.1080/00958972.2014.940922

30. S. T. Hafeez, M. N. Tahir, S. Ali, M. Iqbal, H. Gulab, K. S. Munawar, J. Coord. Chem. 2015, 68, 3636-3650. https://doi.org/10.1080/00958972.2015.1073269

31. Saeed-Ur-Rehman, S. Rehman, M. Ikram, F. Ullah, J. Saudi Chem. Soc. 2013, 17, 353-359. https://doi.org/10.1016/j.jscs.2011.04.012

32. M. A. Halcrow, Chem. Soc. Rev. 2013, 42, 1784-795. https://doi.org/10.1039/C2CS35253B

33. A. W. Addison, T. N. Rao, J. Reedijk, J. van Rijn, G. C. Verschoor, J. Chem. Soc., Dalton Trans., 1984, 1349-1356. https://doi.org/10.1039/DT9840001349
34. N. Alarcón-Payer, T. Pivetta, D. Choquesillo-Lazarte, J. M. González-Pérez, G. Crisponi, A. Castineiras, J. Niclos-Gutiérrez, Inorg. Chim. Acta. 2005, 358, 1918-1926. https://doi.org/10.1016/j.ica.2004.12.056

35. L. J. Daumann, P. Comba, J. A. Larrabee, G. Schenk, R. Stranger, G. Cavigliasso, L. R. Gahan, Inorg. Chem. 2013, 52, 2029-2043. https://doi.org/10.1021/ic302418x

36. M. Iqbal, S. Ali, Z. Rehman, N. Muhammad, M. Sohail, V. Pandarinathan, J. Coord. Chem. 2014, 67, 1731-1745. https://doi.org/10.1080/00958972.2014.926337

37. Y. Sikdar, R. Modak, D. Bose, S. Banerjee, D. Bienko, W. Zierkiewicz, A. Bienko, K. D. Saha, S. Goswami, Dalton Trans. 2015, 44, 8876-8888.

https://doi.org/10.1039/C5DT00752F

38. S. H. Sun, Z. G. Sun, Y. Y. Zhu, D. P. Dong, C. Q. Jiao, J. Zhu, J. Li, W. Chu, H. Tian, M. J. Zheng, W. Y. Shao, Y. F. Lu, Cryst. Growth. Des. 2012, 13, 226-238. https://doi.org/10.1021/cg301392p

39. T. R. Cook, Y. R. Zheng, P. J. Stang, Chem. Rev. 2012, 113, 734-777. https://doi.org/10.1021/cr3002824

40. J. Sun, H. Xu, Molecules 2010, 15, 8349-8359. https://doi.org/10.3390/molecules 15118349

41. R. R. Pulimamidi, R. Nomula, R. Pallepogu, H. Shaik, Eur. J. Med. Chem. 2014, 79, 117-127. https://doi.org/10.1016/j.ejmech.2014.03.084

42. N. Sohrabi, J. Pharm. Sci. Res. 2015, 7, 533-537.

43. D. Tiwari, A. K. Mishra, S. B. Mishra, B. B. Mamba, B. Maji, S. Bhattacharya, Spectrochim. Acta Part A 2011, 79, 1050-1056. https://doi.org/10.1016/j.saa.2011.04.018

44. R. Gomathi, A. Ramu, A. Murugan, Bioinorg. Chem. Appl. 2014, 2014, 215-230.

45. J. Borowska, M. Sierant, E. Sochacka, D. Sanna, E. L. Chruscinaska, J. Bio. Inorg. Chem. 2015, 20, 989-1004. https://doi.org/10.1007/s00775-015-1282-2

46. R. Miyazaki, H. Yasui, Y. Yoshikawa, Open J. Inorg. Chem. 2016, 6, 114-124. https://doi.org/10.4236/ojic.2016.62007

47. Y. Yoshikawa, R. Hirata, H. Yasui, H. Sakurai, Biochimie 2009, 91, 1339-1341. https://doi.org/10.1016/j.biochi.2009.06.005

48. P. Tripathi, M. M. Kumar, M. Chinmayi, T. Ruchita, S. L. Kant, P. K. Bihari, K. Arti, Res. J. Chem. Sci. 2013, 3, 54-59.

49. M. Qazzaz, R. A. Ghani, M. Metani, R. Husein, A. L. AbuHijleh, A. S. A. Ghani, Biol. Trace Elem. Res. 2013, 154, 88-96. https://doi.org/10.1007/s12011-013-9697-5

50. M. Zhou, J. H. Zhou, Y. Meng, M. B. Chen, J. Chem. Theory Comput. 2006, 2, 157-165. https://doi.org/10.1021/ct050168g

51. H. Park, K. Y. Hwang, Y. H. Kim, K. H. Oh, J. Y. Lee, K. Kim, Bioorg. Med. Chem. Lett. 2008, 18, 3711-3715. https://doi.org/10.1016/j.bmcl.2008.05.056

52. Y. M. Cui, X. W. Dong, W. Chen, W. J. Wang, Y. G. Li, H. L. Zhu, J. Enzym. Inhibit. Med. Chem. 2012, 27, 528-532. https://doi.org/10.3109/14756366.2011.599065

53. S. Wanninger, V. Lorenz, A. Subhan, F. T. Edelmann, Chem. Soc. Rev. 2015, 44, 4986-5002. 
https://doi.org/10.1039/C5CS00088B

54. B. M. Paterson, P. S. Donnelly, Chem. Soc. Rev. 2011, 40, 3005-3018. https://doi.org/10.1039/c0cs00215a

55. Y. C. Chan, A. S. M. Ali, M. Khairuddean, K. Y. Khaw, V. Murugaiyah, A. Basiri, Chinese Chem. Lett. 2013, 24, 609612. https://doi.org/10.1016/j.cclet.2013.04.013

56. G. M. Sheldrick, SHELX Release 97.2 ed., University of Gçttingen, Gçttingen, 1997.

57. L. J. Farrugia, J. Appl. Crystallogr. 1999, 32, 837-838. https://doi.org/10.1107/S0021889899006020

58. L. J. Farrugia, J. Appl. Crystallogr. 1997, 30, 565-566.
https://doi.org/10.1107/S0021889897003117

59. G. L. Ellman, K. D. Courtney, V. Andres, R. M. Featherstone, Biochem. Pharmacol. 1977, 7, 88-95. https://doi.org/10.1016/0006-2952(61)90145-9

60. F. S. Aziz-ur-Rehman, N. Afza, A. Malik, L. Iqbal, M. A. Rasool, M. I. Ali, R. B. Tareen, J. Enzym. Inhibit. Med. Chem. 2009, 24, 1128-1132.

61. V. Gorun, I. Proinov, V. Baltescu, G. Balaban, O. Barzu, Anal. Biochem. 1978, 86, 324-326. https://doi.org/10.1016/0003-2697(78)90350-0

\section{Povzetek}

Sintetizirali smo dva nova dvojedrna bakrova(II) karboksilata $\mathrm{z}$ O-mostom s kemijsko formulo [Cu ${ }_{2}(3-\mathrm{Cl}-$ $\left.\mathrm{C}_{6} \mathrm{H}_{4} \mathrm{CH}_{2} \mathrm{COO}\right)_{4}$ (phen) $\left.)_{2}\right](\mathbf{1})$ in $\left[\mathrm{Cu}_{2}\left(3-\mathrm{ClC}_{6} \mathrm{H}_{4} \mathrm{CH}_{2} \mathrm{COO}\right)_{4}(\text { bipy })_{2}\right](2)$, kjer je phen $=1,10$-fenantrolin in bipy = 2,2'bipiridin, ter ju okarakterizirali z FT-IR in UV-vidno spektroskopijo, CHN analizo in monokristalno rentgensko difrakcijo. Strukturna analiza razkriva popačeno kvadratno-piramidalno geometrijo okoli vsakega bakrovega centra $\mathbf{v}$ in 2. Študij interakcij z DNA kaže na močno vezavo s $K_{\mathrm{b}}=5.07 \times 10^{3}$ in $4.62 \times 10^{3} \mathrm{M}^{-1} \mathrm{za} \mathbf{1}$ in 2 . Oba kompleksa izkazujeta močno inhibicijo encimov in sicer $70 \%$ in $90 \%$ inhibicijo $\alpha$-glukozidaze z $\mathrm{IC}_{50}=34.6$ in $30.1 \mu \mathrm{M}$ za $\mathbf{1}$ in 2 , pri čemer smo uporabili akarbozo kot kontrolo. Oba kompleka pa sta neaktivna proti $\alpha$-amilazi. Ob uporabi galantamin hidrobromida kot kontrole, 1 izraža delno inhibitorno aktivnost $(47 \%) \mathrm{z} \mathrm{IC}_{50}=179.4 \mu \mathrm{M}$ proti acetilholin esterazi, medtem ko 2 izraža močno inhibitorno aktivnost $(76 \%) \mathrm{z} \mathrm{IC}_{50}=95.8 \mu \mathrm{M}$ proti butirilholin esterazi. Rezultati kažejo anti-diabetično in anti-Alzheimerjevo delovanje obeh sintetiziranih kompleksov. 